This is an author produced version of a paper published in Property Management. This paper has been peer-reviewed but does not include the final publisher proof-corrections or journal pagination.

Citation for the published paper:

Palm, Peter. (2013). Strategies in real estate management : two strategic pathways. Property Management, vol. 31, issue 4, p. null

URL: https://doi.org/10.1108/PM-10-2012-0034

Publisher: Emerald

This document has been downloaded from MUEP (https://muep.mah.se) / DIVA (https://mau.diva-portal.org). 
Peter Palm

Lecturer Malmö University

Urban studies

Malmö University

20506 Malmö

Sweden

Peter.palm@mah.se

+46(0)40-665 7711

\title{
Strategies in Real Estate Management: two strategic pathways
}

\begin{abstract}
Purpose - The purpose of this paper is to identify different strategic pathways for structoring the real estate management organization. Different strategic pathways regarding commercial real estate organizations, and the alignment of their business models with the environment are studied and outlined.

Design/methodology/approach - This research is based on an analysis of 15 interviews with top-level managers in the Swedish commercial real estate sector.

Findings - When making strategic plans for a company, the commercial real estate industry has two strategic pathways to consider regarding real estate management. The first is to choose whether to have its own frontline personnel or to outsource this function. The second is to decide how the leasing task should be treated: Should it be treated as a real estate manager's task or should it be a function of its own in the organization? The conclusion of the study is that the organizations studied can be structured using both pathways, and the firm can still be successful. Furthermore, the argument by the top-level managers are the same regardless of how their organization is structured. They all base their strategic plans on the view that their structure of the organization is the best way to take care of the customer. In other words, they have the same arguments but haves chosen different strategic pathways to achieve strategic fit.
\end{abstract}

Research limitations/implications - The research in this paper is limited to the Swedish commercial real estate industry.

Originality/value - This paper outlines the strategic pathways for real estate management from a top-level management view.

Keywords - Strategic planning, Real estate management, Strategic fit, Organizational structure

Paper type Research paper

\section{Introduction}

In order to survive and succeed in a competitive market, companies need to develop and maintain an alignment with their environment. The strategy literature emphasizes strategies designed to enable a fit between the firm and the environment in order to obtain and retain new customers. In the context of commercial real estate (in which properties are held as an investment asset and managed with their own property management), the market has become more competitive (Lind and Lundström, 2011). This competitiveness has forced the real estate industry to develop a more service-oriented approach (Palm, 2011). Regarding the field of strategies in commercial real estate, the industry must align its business model with the environment to match its customers' needs and to enable the delivery of necessary services. 
An inventory of the research field of the real estate industry reveals a lack of empirical research on business models in relation to service delivery and customer interaction. Instead, most research is either on the subject of how to involve the company's properties in the corporate strategy (see, for example, Ali et al., 2008 or Scheffer et al., 2006) or the financial aspect of the field (see, for example, Wofford et al., 2011). Some work has also been done on whether to outsource property management or not, but again, many of these studies (for example, Ghodeswar and Vaidyanathan, 2008) have been conducted on corporations whose core business is not real estate. A lack of research regarding real estate companies' strategies for the organization of management is also detected; however, there are exceptions. For example, Hewlett (1999) acknowledges that the organization of real estate companies is a vital component in their strategic planning, which has as its aim to deliver customer satisfaction, although he regards strategies for customer satisfaction as a part of "efficiency strategy" a set of strategies that reduces the cost of doing business. Moreover, Wilson et al. (2001) conclude that the real estate industry understands the need to provide not only high quality products but also services to their customers. Nevertheless, it is acknowledged that business strategy geared toward delivering value to customers is critical (see, for example, Teece, 2010).

Currently, the real estate industry is facing new challenges as a part of an increasingly competitive sector (Wilson et al., 2001). Apple-Meulebrock (2008) concludes that in order to survive in this new, competitive environment, imperativeness of delivering good service is required, a factor that Anderson and Sullivan (1993) also state as crucial to be able to compete. Consequently, the real estate industry will be forced to develop strategies for organizing companies and preparing them to meet these new challenges. Considering the different companies involved in the industry and the different models they use for doing business, their underlying rationale has become a point of interest. How does a real estate company choose to organize itself and its internal abilities to match the challenges of the external environment, and what elements does it regard as critical to ensure success in the market? This article investigates the commercial real estate company's strategies for organizing its property management in order to enable success.

This article uses the term strategy in relation to real estate to refer to a distinct plan for property management on the business level. Traditionally, the term strategic business management is used to describe a clearly defined plan aiming to optimise its capacity (Edwards and Ellison, 2004). Hewlett (1999) states, "companies with a well-defined business strategy have the distinct advantage of having clearly articulated a plan with a common direction for the company."

The scope of this article is to empirically identify arguments for structuring the organization of real estate management in relation to different strategic pathways. The purpose of the article is neither to define an optimal strategy nor to rank them, but merely to identify the arguments for different strategic paths of organizing property management.

\section{Theoretical background}

This section of the article consists of three parts: At First, a general discussion of the concept of strategy and a clarification of this article's standpoint in the strategy jungle are outlined. 
Secondly, the concept of strategic planning will be is discussed. Third, the concepts of fit and environment are outlined.

In the past decades, strategy has received great interest from both researchers and practitioners. As a result, it has been variously described and defined. It has, for example, been described as top management planning for the future (Grant, 2010). It has also been described as the policies of the organization or as a tool to provide the organization with goals and visions. The theoretical standpoint and approach to strategy is what Whittington (2001) defines as a classical approach. Strategy is viewed as a rational process of well-analysed, deliberate choices aiming to maximise the organization's profits and benefits over time. From this perspective, efficient planning is essential to be able to govern the organization's inner and outer environment, and it is the top management's task to formulate, substantiate, and implement these plans. This implies that the core of strategy is deliberate and that the top management's task is to analyse, plan, and implement a deliberate process in order to maximize the organization's profit. Ansoff (1984) describes strategy as a systematic approach for management to position and relate the firm to its environment in a way that enables continued success. Once the general standpoint regarding the strategy field is outlined, the concept of strategic planning can be discussed.

The strategic planning process has historically been viewed as a bureaucratic and rigid activity, in which the main focus has been financial control with no incentive to change or develop (Mintzberg, 1994; Bonn and Christodoulou, 1996). Partly as a result of this criticism, strategic planning has undergone a substantial change since the 1980s (Aldehayyat and Anchor, 2010). There is now less bureaucracy and more emphasis on implementation and innovation as well as more participation from managers and employees. Strategic planning has also been critiqued for other reasons, from not being organic to being something that emerges within organizations rather than being planned (Mintzberg et al., 1998). Whittington (2001) concludes that companies need strategic planning to rationalize their choices because it is what the dominant professional groups and cultural norms demand. In other words, there can be much criticism towards strategic planning, but as long as the culture of the general business environment expects and demands plans, the industry will continue to design and work with them. It is this perception that makes it interesting to investigate plans and to ascertain why top management design them the way they do.

Within the classical view of strategy, it is the chief executive officer (CEO) who is the central actor. In modern strategic management, on the other hand, O'Shannassy (2003) concludes that there is a bottom up information flow in which middle managers participate in strategy formulation, whereas traditionally they just implemented it. This view is shared with Liedtka (2000), who describes the strategic planning process as a link between the members of the organization, the top management, and the initiated change within the company. Furthermore, O'Shannassy maintains that the CEO is not the top strategic leader responsible for strategy formulation but the chief designer of the strategy process facilitating the strategic conversation. Whittington (2001) concludes the following:

For every manager, the strategy-making process starts with a fundamental strategic choice: which theoretical picture of human activity and environment fits most closely with his or her own view of the world. (Whittington, 2001, p. 118) 
Given that strategy is deliberate and can be planned, it is also logical to think that the strategic plan must work as an alignment mechanism between the firm and its environment (Raymond and Bergeron, 2008). This takes us to the third part of the section, where the concept of fit between the firm, its organization, and its environment is explored. Caves (1980) states that it is the top manager's perception of the market structure and the firm's strengths and weaknesses that determines the strategy of the company. It has been argued that the top management's choice of strategies is made through cognitive structures reflecting the perception of the industry. If everyone is doing things a certain way, we should follow suit (Dutton and Jackson, 1987). Caves (1980) concludes that this kind of relation between the company and its market environment is at the intersection of industrial organization and business strategy. Porter (1981) states that successful firms must adapt their strategies to their external environment and that this is best studied at the business level (as defined by Morrison and Roth, 1992; Hawes and Crittenden, 1984; Porter, 1981) because this is where they can have the greatest impact. To establish a fit between the company's capabilities and its potential, knowledge of the possibilities must be acquired. The possibilities are on the market and, in the case of real estate management, are set by the tenant/customer. For the real estate manager, a deep understanding of user needs is vital. Teece (2010) states that this is crucial for the design of the business model. The business model embodies nothing less than the capability of its organization for value creation. Value creation is obtained by aligning the company's internal opportunities with the external environment.

The core of strategic planning is to provide the organization with a model that acknowledges the external threats to and internal opportunities of the business. The company's strategy is to match the internal capabilities and the external possibilities, a match referred to as a "fit" (Mintzberg et al., 1998). Fit is considered a fundamental concept in strategy (Venkatraman and Camillus 1984), and its role is to highlight the company's market opportunities and the organization's competences and resources to enable a match or alignment (Venkatraman, 1989). When planning strategies for the internal structure to fit the environment, differences between strategies to obtain and retain new customers can be identified.

In the field of real estate, the customer is the tenant, and the cost of obtaining new customers can exceed the cost of retaining present customers (Matzler and Hinterhuver, 1998; Li, 2003). If a satisfied customer can lease larger properties, there is an even greater incentive to work with retaining strategies. At the same time, it is very costly for a real estate company to have empty properties: the costs are there regardless, and the market value can be affected as well. There is, therefore, a strong incentive to have well-outlined strategic plans outlining how to attract new customers. However, the most important task is to work with your present customers to prevent them from moving since the cost of retention is less than the cost of attracting new customers (Matzler and Hinterhuver, 1998; Li, 2003).

It is the real estate management team's task to work with these questions in an efficient way. Baldwin (1994) and Ling and Archer (2010) state that it is the real estate manager's task to supervise, coordinate, and control all activities related to the property. Loh (1991) and Wurtzebach et al. (1994) also include that the dimension of the real estate manager is to maximize returns by increasing rental income. These goals are divided by Abdullah et al. (2011) into two categories: short- and long-term objectives. The fulfilment of short-term objectives (like the task of maintenance, rent reviews, leasing, and customer relations) is a requirement that need to be fulfilled prior to ensuring long-term objectives (like increasing investment returns, optimizing property usage, and prolonging the functional life) are fully met. Abdulla et al. also conclude that the function of real estate management is a mixture of 
the achievement of financial objectives and practical management issues, which maintain investment on one hand and customer value on the other.

This article will focus on the practical management tasks. These tasks are divided by Blomé (2010) into three different elements: Customer service, Leasing, and Caretaking. The task of customer service includes the possibility to make fault reports and get in touch with the responsible staff. The task of leasing incorporates the process of marketing, tenant selection, contract writing, and so on. The task of caretaking includes day-to-day activities and control over in- and outdoor areas; it contains tenant consultations, day-to-day care of property, maintenance, solving problems related to fault reports, repairs, and so on. Leaving aside the task of customer service because it is most often is done electronically or by direct contact with the personnel in charge, there are two tasks left: leasing and caretaking. Blomé (2010) and Ling and Archer (2011) conclude that these tasks can be organized in two different ways, which can be seen as two strategic pathways since the structure of the organization would have been preceded by a strategic decision dependent on the strategic plan outlined by the senior management.

The first decision is whether to outsource the task of caretaking or to keep the function of frontline personnel ${ }^{1}$ in-house. There is a vast discussion in the literature regarding the strategic decision of outsourcing. The theoretical base of the discussion can be found in the transaction cost theory (Hätönen and Eriksson, 2009), a trend that can also be seen within the field of real estate management. In the transaction cost theory, the foundation of the argument regarding outsourcing is that tasks can be more efficiently organized when carried out by larger units. This argument goes back to Coase's work in 1937 (cited in Hätönen and Eriksson, 2009); he suggests that tasks should only be organized within a firm when the cost of doing so is lower than the price on the market. The second strategic decision regarding how to structure the organization pertains to leasing. Should the leasing function be regarded as a task for the individual property manager, or should it be regarded as a centralised task with specialised employees? This question determines whether the organization should assign specialized leasing managers or not.

Both decisions are central strategic decisions to be made by the top-level management when structuring their organization. When considering both these tasks as central questions for structuring the organization and at the same time viewing strategy as something that can be planed, the organization should be planned to fit the company's environment. The organization should be structured to align with the environment to maximise profit. This strategic fit between the organization and the environment should be central in the top-level managers work when making the strategic plan of how to structure the organization. Due to a competitive environment, companies with an organization lacking alignment with the environment should have difficulties to compete on the market.

\section{Research design and methodology}

The foundation of this article is an interview study with top-level managers in the real estate industry. The concern of the study was to identify the top management's view regarding the strategic choices made in the company's business model. Teece (2010) concludes that a

\footnotetext{
${ }^{1}$ In this article, frontline personnel is defined as all personnel in day-to-day contact with the customers, such as janitors, technicians, service personnel, and so on.
} 
business model describes the design of the value creation for the company. By collecting strategic views regarding the design of the business model, an understanding for the typology of the company's strategic plan and its alignment with the environment should be possible.

\subsection{Data collection}

For this study, a selection of 16 companies (together managing approximately $20-25 \%$ of the property values in Sweden) was made through a stratified purposeful sampling, as defined by Eisenhardts (1989) and Patton (2002). From the 16 companies chosen, one listed company decided not to participate. The outcome should not be affected since it was a company from the group of listed companies, and this group is well represented in the study since it consists of nine of the total 16 listed commercial real estate companies in Sweden. Stratified purposeful sampling was used to enable a representation of organizations with different characteristics. These characteristics include size, ownership, and most importantly, organization of the real estate management. This is because the study's aim was to investigate the top-management's arguments regarding the strategic plan of how to structure the organization. Since only a limited number of cases can be studied, the selection should be strategic; whereas, the process of selection is transparently observable. Since this study does not try to make any statistically evident conclusions of the commercial real estate business, strategic selection is preferred. This research design strives to categorise within-group similarities coupled with intergroup differences. For the study in this paper, the following four categories were chosen: family, listed, institutional, and privately owned companies. The selection of these four specific categories facilitated the discussion on a more general level concerning the commercial real estate sector in Sweden.

The distribution of the participating companies can be seen in Table I. Furthermore, Table I shows a categorization of the companies according to size. They are categorised as "Small" or "Large". To be categorised as "Small", the company should have a revenue between $€ 50$ million and €999 million; to be categorised as "Large," it should have a revenue of $€ 1,000$ million or more. The reason behind excluding companies with a revenue under $€ 50$ million is because they usually do not have the same strategic prerequisite when it comes to organizations due to their size.

Table I. Participating companies

$\begin{array}{lccc} & \text { Small } & \text { Large } & \text { Total } \\ \text { Listed } & 5 & 4 & 9 \\ \text { Private } & 2 & & 2 \\ \text { Institutional } & 1 & 1 & 2 \\ \text { Famliy } & 2 & & 2 \\ \text { Total } & 10 & 5 & 15\end{array}$

The interviews with the top-level managers of the 15 companies were conducted during the winter of 2010. Eisenhardt and Graebner (2007) state that a key approach to mitigate a bias in interview studies is to combine it with retrospective material. In this study, all interviews have been preceded by a study of annual reports from the previous five years for each company. The study of annual reports allowed the design of this interview study to follow a general structure and, at the same time, to focus each interview on the specific company interviewed. 
The design of the interview process is based on Kvale's (1995) structure for semi-structured interviews. The foundation for the interviews was the more comprehensive question regarding the company's business model. At the same time, every interview had its own unique starting point since all of the interviews started with the individual business model of each company and how it presented itself in its annual reports. The basic intention with this was to be able to run each interview as a conversation about the individual company and its unique situation. Each top-level manager then continued to describe the background to the strategic decisions which preceded the business model and the way the company was organized. The follow-up questions were all based on the strategic concepts identified from the literature of real estate management, including Ling and Archer (2010), Larsen (2003), and Wurtzebach et al. (1994). Designing the interviews with foundations in the organization at hand and the literature allowed the top managements to describe the strategic plans in a more in-depth way. The result gave an insight of the top management's underlying rationale regarding the organization's design of its strategic plans.

\subsection{Data analysis}

To enable sorting, interpreting, classifying, and coding of the interview material, all interviews were recorded and all of the material was then transcribed. This working procedure enables a better overview and understanding of the material while securing the process and ensuring that the respondents are correctly quoted. Taping and transcribing is also a working procedure that is considered essential when working with this type of interview material (see, for example, Riessman, 1993).

The concept of interviewing the top-level managers with a starting point in the literature and reflecting each company's unique situation resulted in interview material that was similar to stories from the top management. The interview study carried on as long as there were useful interpretations; this achieved saturation in the material (Patton, 2002; Steiner, 2003) and gave the study a body of concepts that linked the stories together. The interview material was then combined using profiles based on the literature of real estate management and the descriptions each top-level manager had given. Gradually, two concepts arose, describing the strategic plan behind the real estate management for the companies studied: in-house frontline personnel or outsourcing and leasing as a central function or as a management task.

\section{Real estate management strategies}

This section examines the outcome of the 15 interviews regarding the strategic pathways chosen. The outcome is placed in a strategic context and discussed from that viewpoint. The section is divided into two subsections. First, an overview of the material is displayed. Afterwards, the next two subsections categorise the interview material under the two strategic pathways. The purpose of categorising the findings under these two concepts is to structure the material to improve comprehension. The use of categorisation of the findings through concepts is also found in the theory of corporate culture and identity (see, for example, Steiner, 2003 or Bourgeois and Eisenhardt, 1988).

The literature suggests that when building a real estate management organization, the questions regarding frontline personnel and the leasing function are treated as central questions (Ling \& Archer, 2010; Larsen, 2003; Wurtzebach et al., 1994). These two questions 
are considered as two strategic and alternative pathways. Table II summarizes the evidence for the strategic paths chosen.

Table II. Strategic paths chosen

\begin{tabular}{|c|c|c|c|c|c|}
\hline \multirow[b]{2}{*}{ Ownership } & \multirow[b]{2}{*}{ Size } & \multicolumn{2}{|c|}{ Frontline personnel } & \multicolumn{2}{|c|}{ Leasing } \\
\hline & & In-house & Outsourcing & Manager task & Centralised function \\
\hline Listed & Small & & $\mathrm{x}$ & $\mathrm{x}$ & \\
\hline Listed & Small & & $x$ & & $\mathrm{x}$ \\
\hline Listed & Small & $\mathrm{x}$ & & $\mathrm{x}$ & \\
\hline Listed & Small & $x$ & & & $\mathrm{x}$ \\
\hline Listed & Small & $x$ & & & $x$ \\
\hline Listed & Large & & $x$ & $x$ & \\
\hline Listed & Large & $x$ & & & $x$ \\
\hline Listed & Large & $x$ & & & $x$ \\
\hline Listed & Large & $x$ & & $\mathrm{x}$ & \\
\hline Private & Small & $x$ & & $x$ & \\
\hline Private & Small & $x$ & & & $x$ \\
\hline Family & Small & & $x$ & $x$ & \\
\hline Family & Small & $x$ & & $x$ & \\
\hline Institutional & Small & $\mathrm{x}$ & & & $\mathrm{x}$ \\
\hline Institutional & Large & $\mathrm{x}$ & & & $\mathrm{x}$ \\
\hline Total & & 11 & 4 & 7 & 8 \\
\hline Listed = 9 & $S=10$ & & & & \\
\hline Private $=2$ & $L=5$ & & & & \\
\hline Family = 2 & & & & & \\
\hline
\end{tabular}

From Table II, a remarkable spread is seen regarding the strategic choice of respondent companies to organize their property management. Regarding the function of frontline personnel, either in-house or outsourced, the companies in the study tend to have their own frontline personnel. The companies' preference is less clear when it comes to leasing. Of the fifteen companies, seven regard it as a real estate manager's task, while eight regard it as a function that should be centralised within the organization. The situation is summarised in Table III, which shows that the most common way to organize property management is to have in-house frontline personnel and to consider leasing as a function of its own in the organization.

Table III. Frontline personnel and leasing as strategic pathways

\begin{tabular}{llccc} 
& & \multicolumn{3}{c}{ Leasing } \\
Frontline & In-house & 4 & 7 & Manager task \\
personnel & Centralised function & Total \\
& Outsourcing & 3 & 1 & 11 \\
& Total & 7 & 8 & 4
\end{tabular}

\subsection{In house frontline personnel or outsourcing}

When building your organization, one essential question is whether you should run your business with your own personnel or not. This article is based on interviews with real estate companies with their own property management organization, but they also have the decision of whether to use their own frontline personnel or not. Table IV summarises the top- 
managers' arguments on why to organize the frontline personnel task in-house compared to outsourced.

Table IV. Arguments regarding frontline personnel function

\section{Frontline personnel}

In-house

Direct contact with customer

Short decision paths

In charge of the question

Effective management

\section{Outsourcing}

Customer focus

Local function

flexibility

Service to the customers

Examples of how two top-level managers view the strategic choice to have their own frontline personnel are presented below:

We have built our organization entirely with our own personnel because it is so important for us to have control over the customer - that we have contact directly with the customer. If there is something the customer thinks is wrong or not up to standards, it can easily be addressed directly to us. We don't have many intermediate links between the customer and the person in charge. If you have consultants involved doing work for you, that will maybe not happen. Because they have always their own goals, their own business model, or whatever, that means that they are never working $100 \%$ for you and your goals. For example, it is always best for the owner that the tenant stays. But it isn't sure if you use a consultant for the management because maybe it isn't in their best interest that the tenant stays. Maybe they will earn more if there is a little rotation of tenants. (Small Privately owned company representative)

For this company, the strategic choice to have in-house frontline personnel is based on the fact that they want to own the entire process and to "own" the problem themselves. They want to know that things are up to their required standards and to be able to control the situation.

We have an organization locally at every locality-with management, leasing, and operation - so that we can daily serve our customers and meet their needs. We don't buy these kinds of services. Several companies do buy parts of it, but we keep it in-house since we see it as strategically important to be able to find this kind of effective management that can make solid investment decisions. (Small Family owned company representative)

This citation points at two more factors, besides having control of the situation. One is that they see having in-house frontline personnel as strategically important since they want to be able to make the management more effective; they need to own the function. The other factor is that, in order to make solid investment decisions, they need to have frontline personnel competence in-house.

An example of how one top-level manager views the strategic choice to have in-house frontline personnel is set out below: 
We have outsourced the maintenance and operations, but we make all of the important decisions ourselves. This is because we have decided to be customer-focused. This way, our property managers will be $100 \%$ focused on the customer instead. Even if maintenance is important, especially for the kind of properties we own, we think this way is better. And it is in our business model to own high yield properties that are to give a positive return from the start. We don't buy anything that will start to give a positive return in five years; we want it to start to make money directly. We buy good investments, and when we do so, we don't want to tie ourselves up to anything else (in-house frontline personnel). Therefore, we have chosen to outsource all of the maintenance operations because then we will get a local janitor, and we think that it is important for the property to have that. (Large Listed company representative)

What this citation points out is that they think it is important to have flexibility, and if they were to have their own front personnel, they would lose that flexibility. It also points to the fact that there has to be frontline personnel locally, and if you do not have a large stock of property, you will not be able to run it efficiently.

The points outlined above regarding controlling the situation and being able to have an efficient management can both be tied to alignment with environment. If you are the one doing the work, you will also be the one getting the feedback and have the responsibility to update your services accordingly. When that function is outsourced, you can only update your services by adding or elucidating this requirement in the contract before the contract is due to expire, which is costly, if even possible. Therefore, to enable a fit between the organization and the customer, the companies investigated see in-house frontline personnel as strategically important.

\subsection{Leasing as a manager task or as a central function}

The other essential strategic pathway when planning your organizational structure is deciding where the responsibility for new leasing should lie. When planning, there are two choices: leasing can either be regarded as a task for the individual real estate manager, who is responsible for the property and its customers, or be treated as a separate function that is centralised in the organization and leads to a central sales team in the organization. Summarizing the top-level managers' arguments regarding why to organize the leasing question gives us the outcome shown in Table $\mathrm{V}$.

Table V. Arguments regarding the leasing function

\section{Leasing}

\section{Manager task}

Customer contact

Most important task

Best knowledge of properties

\section{Centralised function}

Customer contact

Most important function

Focus on one task 
Examples of how two top-level managers view the strategic choice to have leasing as a real estate manger's task are illustrated below:

Our property managers don't work with projects. They are out in the field to meet the customers and have the overall picture, Leasing, moving in, administrating, and moving out. They have the process under their umbrella. We have leasing as a manager task because it benefits the customer focus. We see it as a strength also depending on the type of properties that we own. We prefer somewhat longer contracts, and then there is a strength that you have both the customer relation and knowledge of the properties with you in the whole business process. Of course, it is a little vulnerable because it generates a lot to do sometimes, but it is also very interesting and stimulating for the manager to work with the deal. New leasing is perhaps the part that is most fun. It is what we live on. (Large Listed company representative)

The respondent highlights the importance of the real estate manager's knowledge of the overall picture of the property as well as their relationship with the customer. Moreover, he points at the importance of the leasing - it is, as he states, what they live on.

The real estate manager is responsible for the leasing. The reason for this is because it is the real estate manager that has the full responsibility for the property, regarding both costs and revenue. The manager is the one that knows the property best, and it is the manager that makes the strategic plans for the property regarding the operations for the next two to three years. I believe that it is that person who is best suited to lay the puzzle also when it comes to leasing. (Small Listed company representative)

This citation repeats the same facts as before but highlights the fact that it is the real estate manager that will have the responsibility because such an individual is best suited to be responsible for the leasing as well.

An example of how one top-level manager views the strategic choice to organize leasing as a centralised function of its own is pictured below:

The thing is to get the organization to function on a horizontal level. Here you get a lot of delimitations between management and the leasing function. The thing is that a central leasing function can focus on getting things done. If you have a focus, let's say you have a management area where you have leasing, project and management, then you won't get much done regarding projects and leasing. This is because new projects and new leasing will only be done when the market comes to you, not from you working the market. The chief of management cannot handle that at the same time as they have to take care of the current customers. In that case, the service delivered to the customers will suffer. Furthermore, it is a service function for our future customers. If you want to lease from us, you should get the best service available. (Large Listed company representative) 
The main argument from the citation is that it comes down to delivering the best service possible to new customers, and to do so, you have to be one hundred per cent focused on leasing.

The two main reasons for having leasing as a centralised function are outlined by the respondent, and they are focus and customer service. The respondent states that it is not possible to work with leasing and simultaneously attend to your present customers because then it is unavoidable that your service towards the present customers will suffer due to lack of attention. Customer services in the sense that responsibility for leasing requires $100 \%$ devotion to work with new customers and then you cannot have anything else that needs your attention. It also provides guidance for the whole company, not just for the properties that one individual is responsible for.

The argument regarding knowledge of the property is evident since you cannot match future customer needs with specific properties if that information is missing. The real estate manager has that information and will also know if anyone might be interested in renting smaller properties and, thereby, require a new lease. Having leasing as a centralised function, on the other hand, enables your company to lay the customer and properties puzzle on a higher level and considerer all vacancies when talking to a potential customer. The conclusion is that if leasing is done on the real estate manager's level, there needs to be an information flow between the managers and incentives to help your fellow co-worker to let. If leasing is a centralised function, there needs to be a flow of information between real estate managers and leasing managers as well as incentives to lease, even for those not directly responsible. If this information does not flow properly, the company will not be able to match the customers' requirements appropriately, no matter how good the properties.

\section{Two strategic pathways}

The literature on real estate management identifies two strategic pathways related to the strategic planning on how to structure the real estate management organization. It is the function of front-line personnel and leasing. When planning for the structure of the organization, the top-level managers must consider these two strategic questions to enable the best organizational fit to the environment as possible: Should the company outsource or have the front-line personnel in-house? Should the company structure the organization with a centralised leasing function, or should this be regarded as a task for the individual real estate manager? This study regards the top-level managers' arguments behind the strategic plan for structuring the organization in order to make an alignment with the environment.

First, when it comes to frontline personnel, the top-level managers' main argument for structuring their organization with in-house frontline personnel is the organization's direct contact with their customers. The top-level managers representing companies with this organizational structure all regard it as the only way to be able to have an effective management and take good care of their customers. For them, structuring the organization in another way seems as inconceivable as not being a part of the real estate industry anymore. In other words, the respondents all argue that their way of structuring the organization is the only way to enable an organizational fit with the environment. Structuring the organization in any other way would render less control and would not enable them to properly take care of their customers; in other words, it would allow their competitors to gain market shares, and the firm would be overtaken in the long run. 
Considering the arguments from the top-level managers that structured their organization with outsourced frontline personnel, the same kind of worries are displayed. These top-level managers state arguments regarding the possibility to give proper service to their customers. They stress that it would be difficult, if not impossible, to deliver good service without outsourced frontline personnel.

The difference between the arguments for in-house and outsourced frontline personnel, both of which tend to be based within a customer focus or service delivery, is that arguments for in-house consider control of the process while arguments for outsourcing consider flexibility instead. The organizational fit, from the perspective of having both control of the process and having flexibility, seem to be subordinated to the strategic question of customer focus and service delivery, but when structuring the organization to fit with the environment, this is what makes the difference.

Second, when it comes to the leasing task, the top-level managers present arguments for structuring the organization with it as either a manager task among other tasks or as a centralised function; in both cases, they state customer contact as the main argument. Toplevel managers structuring their organization with the leasing function as a manager's task emphasize the importance of the fact that the real estate manager is the one with customer responsibility. This emphasis places the real estate manager as the natural choice for taking charge of the leasing task, being the one with the customer contact in the future as well. The representatives of the other way to structure the organization, with leasing as a centralised function instead, consider it impossible for the individual real estate manager to handle the leasing task. Instead, they stress the importance of having personnel with leasing as their only task. Otherwise, they do not believe that the organization would be able to provide a satisfactory service for their customers.

The interpretation of the arguments of both sides when it comes to leasing is that the structuring of the organization is viewed with customer consideration in mind, but how to handle the task at hand is viewed diametrically differently. As in the question before, both sides see the other way of structuring the organization as just as distant and strange as if you were talking about a completely different business. Both sides have a great scepticism for the other way and cannot imagine that the organization would perform if structured in the other way. Both ways of structuring the organization have their base in customer contact, but their strategic plan to enable the environmental fit is different. However, they both seem to work in a satisfactory manner to the degree that the different top-level managers cannot see how it could work in any other way.

All of the companies within the study are competing in the same arena and facing the same environment. When the top-level managers outline the strategic plan, they should consider the same environment when structuring the organization in order to make the best fit possible and enable business success. It is evident that the argument of top-level managers for structuring their organizations is based on the two strategic pathways described in this study: customer contact and focus. However, the same argument is used regardless of the strategic pathways chosen to enable the fit.

\section{Implication for further research}


The study invites further research regarding how companies make their organizations effective. Each of the companies selected for this study has a solid history, so how can they all manage to survive in the competitive market environment despite having different organizational structures? 
References

Abdullah, Shardy, Arman Abdul Razak and Abd Hamid Kadir Pakir. (2011), The characteristics of real estate assets management practice in the Malaysian Federal Government, Journal of Corporate Real Estate, Vol. 13 No. 1, pp. 16-35.

Aldehayyat Jehad S., John R. Anchor. (2010), Strategic planning implementation and creation of value in the firm, Strategic change, Vol. 19, pp. 163-176.

Ali, Zaiton, Stanley McGreal, Alistair Adair, James R. Webb. (2008), Corporate Real estate strategy: A conceptual overview, Journal of real estate literature, Vol. 16 No 1, pp. 3-21.

Ansoff Igor. (1984), Strategic management, Palgrave Macmillan Basingtoke.

Anderson, Eugene W. and Mary W. Sullivan (1993), The antecedents and consequences of customer satisfaction for firms, Marketing science, Vol. 12, No 2 pp. 125-143.

Apple-Meulenbrock. Rianne. (2008), Managing "keep" factors of office tenants to raise satisfaction and loyalty, Property Management, Vol. 26 No. 1, pp. 43-55.

Baldwin. Greame. (1994), Property management in Hong Kong: An Overview, Property management, Vol. 12. Iss: 4, pp. 18-23.

Blomé Gunnar. (2010), Local housing administrative models for large housing estates, Property management, Vol. 28 No. 5, pp. 320-338.

Bonn Ingrid and Chris Christodoulou. (1996), From strategic planning to strategic management, Long range planning, Vol. 29 No 4, pp. 543-551.

Bourgeoris L. J. and Kathleen Eisenhardt. (1988), Strategic decision processing in high velocity environment: Four cases in the microcomputer industry., Management science, Vol. 34 No.7, pp. 816-835.

Caves Richard E. (1980), Industrial organization, Corporate Strategy and Structure, Journal of Economics Literature, Vol. 18 No 1, pp. 64-92.

Dutton Jane E. and Susan E. Jackson. (1987), Categorizing strategic issues: Links to Organizational action, The Academy of management review, Vol. 12 No. 1, pp. 76-90.

Edwards Victoria and Louise Ellison. (2004), Corporate property management, Blackwell science Ltd. Oxford UK.

Eisenhardts Kathleen. (1989), Building theories from case study research. Academy of management review, Vol. 14. No 4, pp. 532-550.

Eisenhardts Kathleen and Melissa Graebner. (2007), Theory building from cases: Oppertunities adn challanges. Academy of Management Journal, Vol. 50 No. 1, pp. 25-32. 
Ghodeswar, Bhimrao, Janardan Vaidyanathan. (2008), Business process outsourcing: An approach to gain access to World-class capabilities, Business process Management Journal, Vol, 14 No. 1, pp. 23-38.

Grant Robert M. (2010), Contemporary Strategy Analysis and cases $7^{\text {th }}$ ed. John Wily and Sons Ltd

Hawes Jon M. \& William F. Crittenden. (1984), A taxonomy of competitive retailing strategies, Strategic Management journal, Vol. 5. No. 3, pp. 275-287.

Hewlett Charles A. (1999), Strategic planning for real estate companies, Journal of Property Management, Vol. 64 No. 1, pp. 26-29.

Hätönen, Jussi. and Taina Eriksson. (2009), 30+ years of research and practice of outsourcing - Exploring the past and anticipating the future. Journal of international Management, No. 15, pp. 142-155.

Kvale Steinar. (1995), Den kvalitative forskningsintervjun. Studentlitteratur, Lund Larsen James E. (2003), Core Concepts of Real Estate Principles and Practices, Wiley

Li, M. -H. C. (2003), Quality loss functions for the measurement of service quality, International journal of advanced manufacturing technology, Vol 21, Iss 1, pp. 29-37.

Liedtka Jeanne M. (2000), Strategic planning as a contributor to strategic change: A generative model, European management journal, Vol. 18 No. 2, pp. 195-206.

Ling, David C., and Wayne R. Archer. (2010), Real estate principles: a value approach. 3 ed. Boston. McGraw-Hill Irwin.

Lind Hans \& Stellan Lundström. (2011), Kommersiella fastigheter i samhällsbyggandet. SNS Förlag, Stockholm

Loh, Siew C. (1991), Property management: an overview. Surveyor, No. 4, pp. 25-32.

Matzler, Kurt. and Hans H. Hinterhuver. (1998), How to make product development projects more successful by integrating Kano's model of customer satisfaction into quality function deployment, Technovation, Vol. 18 No., 1 pp. 25-38.

Mintzberg Henry., Bruce Ahlstrand and Joseph Lampel. (1998), Strategy safari - A guided tour through the wilds of strategic management, Prentice Hall

Mintzberg Henry. (1994), The fall and rise of strategic planning. Harvard business review, Jan-feb 1994, pp. 107-114.

Morrison Allen J. and Roth Kendall. (1992), A Taxonomy of business-level strategies in global industries, Strategic management Journal, Vol. 13, No. 6, pp. 399-417.

O'Shannassy Tim. (2003), Modern strategic management: Balancing strategic thinking and strategic planning for international and external stakeholders, Singapore management review, Vol. 25 No. 1, pp. 53-67. 
Palm Peter. (2011), Customer Orientation in Real-Estate Companies -the espoused values of customer relations, Property Management, Vol. 29 Iss. 2, pp. 130-145.

Patton Michael Quinn. (2002), Qualitative research \& Evaluation methods 3ed. Sage Thousand Oaks

Porter Michael. (1981), The contribution of industrial organization to strategic management. The academy of management review, Vol. 6 No. 4, pp. 609-620.

Porter Michael (2004), Competitive strategy techniques for analysing industries and competitors, Free Press, New York

Raymond Louis \& François Bergeron. (2008), Enabling the business strategy of SMEs through e-business capabilities A strategic alignment perspective, Industrial Management \& Data Systems, Vol. 108 No. 5, pp. 577-595.

Riessman Catherine Kohler. (1993), Narrative analysis. Qualitative research methods series 30 SAGE University paper.

Scheffer Johannes J.L., Bastian P. Singer, and Marc C.C. Van Meerwiik. (2006), Enhancing the corporate real estate to corporate strategy, Journal of Corporate Real estate, Vol. 8 No. 4 , pp. 188-197.

Steiner Lars. (2003), Roots of identity in Real estate industry. Corporate reputation review, Vol 6, No. 2, pp. 178-196.

Teece, David J. (2010), Business Models, Business strategy and innovation. Long range planning, Vol. 43, pp. 172-194.

Venkatraman N. \& John C. Camillus. (1984), Exploring the concept of "Fit" in strategic management, The academy of management review, Vol 9. No. 3, pp. 513-525.

Venkatraman N. (1989), The concept of fit in strategy research: Toward verbal and statistical correspondence, The academy of management review. Vol. 14 No. 3, pp. 423-444.

Whittington Richard (2001), What is strategy -and does it matter? 2ed. South-Western Cengage learning, London

Wilson C.hris., Joan Leckman., Kahil Cappucino, and Wim Pullen (2001), Towards customer delight: Added value in public sector corporate real estate, Journal of Corporate real estate, Vol. 3 No. 3, pp. 215-221.

Wofford Larry E, Michael L. Troilo, and Andrew D. Dorchester. (2011), Cognitive risk and real estate Portfolio Management, Journal of portfolio managements, Vol. 17 No. 1, pp. 6973.

Wurtzebach Charles H., Mike E. Miles with Susanne Etheridge Cannon. (1994), Modern real estate, 5 th ed. John Wiley \& sons. New York 